\title{
Which way forward in the quest for drought tolerance in perennial ryegrass?
}

\author{
C. MATTHEW ${ }^{1}$, A. van der LINDEN ${ }^{2}$, S. HUSSAIN ${ }^{1}$, H.S. EASTON ${ }^{3}$, J.-H.B. HATIER ${ }^{3}$ and D .J. HORNE ${ }^{1}$ \\ ${ }^{1}$ INR - PN433, Massey University, Private Bag 11-222, Palmerston North 4442 \\ ${ }^{2}$ Centre for Crop Systems Analysis, Wageningen University, \\ P.O. Box 430, 6700 AK Wageningen, The Netherlands \\ ${ }^{3}$ AgResearch Grasslands, Private Bag, 11-008, Palmerston North 4442
}

c.matthew@massey.ac.nz

\begin{abstract}
Pasture moisture stress for "summer" (November to March) was calculated for five main pastoral regions of New Zealand, and 9 or 10 years' weather data were modelled in each case. Amelioration of water deficit with deeper rooting, stronger plant tissue osmotic potential for greater water extraction, or increased photosynthetic water use efficiency (WUE) was also modelled. Regional mean summer moisture deficits ranged from $34 \mathrm{~mm}$ in Taranaki to $447 \mathrm{~mm}$ in Canterbury. For a $10-\mathrm{cm}$ increase in rooting depth, the model predicted an additional $16 \mathrm{~mm}$ water extraction. Increased plant osmotic potential was predicted to only slightly increase water extraction and paradoxically reduce yield. The assumed increase in photosynthetic WUE improved production by $240 \mathrm{~kg} \mathrm{DM} \mathrm{ha}{ }^{-1}$ for the same water use. Drought tolerance traits exhibited by a range of ryegrass cultivars were measured in a series of glasshouse experiments and the potential to improve New Zealand ryegrass drought tolerance by introgression with germplasm originating from North Africa was assessed. North African germplasm possesses a trait of deep rootedness but has low summer productivity as a soil moisture conservation strategy and a high percentage of tillers flowering, so initial evaluations of this material for suitability for use in New Zealand are not promising. Ryegrass cultivars incorporating germplasm of Spanish origin appear to maintain summer production with enhanced WUE.
\end{abstract}

Keywords: drought tolerance, root depth, Lolium perenne, perennial ryegrass, water deficit

\section{Introduction}

Perennial ryegrass (Lolium perenne L.) is now firmly established as the grass species of choice for new pasture sowings in most regions of New Zealand. Early developments in ryegrass improvement in New Zealand were the establishment of a plant research station in Palmerston North in 1928 and the introduction of a variety certification scheme in 1929 (Hunt \& Easton 1989). There was an initial selection focus on yield, rust resistance and winter growth capacity. More recent developments have been reviewed by Stewart (2006) and Lee et al. (2012). Three main sources of germplasm were listed by Stewart (2006) as important in the development of modern New Zealand ryegrass cultivars: (i) the descendants of lines released by the Palmerston North Station in the 1930s and derived from Hawke's Bay permanent pasture ecotypes; (ii) a so-called 'Mangere' ecotype from which cultivars 'Grasslands Nui' and 'Ellett' and their successors were selected; and (iii) seed collections from Galicia in Spain (a region climatically similar to Northern New Zealand).

Currently there is industry concern about perceived problems with ryegrass persistence, especially in warmer regions of New Zealand (see e.g., Glassey 2011), and hence an increasing focus on how best to improve moisture deficit tolerance in perennial ryegrass. Industry focus on cultivar performance is evidenced by the recent introduction of a dairy forage value index (DairyNZ 2012).

While plant breeders have been concerned about these issues, and much information has been collected and collated, there remains a lack of clarity about questions such as (i) regional and inter-annual variation in summer moisture deficit within New Zealand, (ii) breeding traits that are likely to provide the greatest gains in drought tolerance, and (iii) the germplasm sources most likely to provide desired traits. In this paper data from the National Institute of Water and Atmospheric Research (NIWA) are used to explore regional and inter-annual variation in summer moisture deficit, employing a pasture growth simulation model to explore implications of the modelled moisture deficit for ryegrass performance, and model outcomes of alternative breeding targets related to moisture deficit tolerance. We also present selected data from three glasshouse experiments, designed to compare the drought tolerance traits of ryegrass cultivars 'Grasslands Samson' and 'Tolosa', and to explore the potential for improving ryegrass drought tolerance by introgression with cultivar 'Medea', developed in 
Australia from germplasm of Algerian origin (Silsbury 1961; Reed 1996).

\section{Methods}

\section{Model overview and modelling work}

The climate investigation work used the simulation model LINGRA (LINtul-GRAss) developed in Wageningen at the DLO Research Institute for Agrobiology and Soil Fertility, calibrated for perennial ryegrass (Schapendonk et al. 1998). This model uses the Fortran Simulation Environment (FSE) (Kraalingen 1995). Required inputs are daily weather data including solar radiation, rainfall, minimum and maximum air temperature, vapour pressure and wind speed, as well as light use efficiency (3.0 $\mathrm{g} \mathrm{DM} \mathrm{MJ}^{-1}$ photosynthetically active radiation) and nitrogen concentration of herbage $(0.7 \% \mathrm{~N}$, selected to model yields with water nonlimiting of $\left.15-20 \mathrm{t} \mathrm{DM} \mathrm{ha}^{-1} \mathrm{yr}^{-1}\right)$. These, and other inputs, are used by the model to determine coefficients that are applied multiplicatively in determining yield.

Weather data were obtained from the CLIFLO database (NIWA 2012). Ten-year daily sequences of weather data were collected for five locations: Hamilton (NIWA Agent Numbers (NAN) 12616 and 26117); Palmerston North (NAN21963), Lincoln (NAN17603) and Invercargill (NAN11104) for 2002-2011 inclusive, and a 9-year sequence (2003-2011) for Stratford, Taranaki (NAN23872). These weather stations were chosen for comparative completeness of the records, and were assumed to be representative of the weather in their respective regions.

Calculations for each year's weather data in each region required a discrete model run, making 49 runs in total to process the regional data. Model outputs collated for each region were: annual herbage production predicted with a non-limiting water supply; expected production considering actual weather data; and "summer" evapotranspiration (ET) deficit (i.e., rainfall - evaporation - transpiration). For the study, November to March inclusive was considered to be the key period in determining summer moisture deficit. To provide the soil physical parameters required by LINGRA, data for soil parameters of the various regions were "standardised" to those of a "typical" soil based on a Manawatu Silt Loam (A.S. Palmer, personal communication; porosity $51.8 \%$, percolation rate 1.20 $\mathrm{m}$ day $^{-1}$, volumetric water holding capacity $17.5 \%$ ).

Also, three breeding targets potentially relevant to increasing tolerance of ryegrass to moisture deficit were identified and modelled for Manawatu weather data, to assess their predicted effect: (i) deeper rooting: from $40 \mathrm{~cm}$ to $50 \mathrm{~cm}$ rooting depth (LINGRA parameter ROOTD changed from 0.4 to $0.5 \mathrm{~m}$ ); (ii) more negative osmotic potential (OP) of plant tissues, modelled as a decreased critical water content (i.e. the volumetric soil moisture content below which soil dryness is deemed by the model to limit transpiration; LINGRA parameter WCCR changed from $26.85 \%$ to $25.60 \%$ ). This decrease in critical water content equates to root OP becoming more negative by approximately $0.4 \mathrm{MPa}$; (iii) a $10 \%$ increase in photosynthetic water use efficiency (WUE) under dry conditions (LINGRA parameter TRANRF decreased by 10\%; the effect of this change is to partially remove the reduction of photosynthesis triggered in the model at the onset of drought). Again, a 10-year weather data sequence was run for each scenario, making 30 discrete model runs to evaluate the breeding target scenarios.

Table 1. Regional and inter-annual variation in November-March moisture deficit within New Zealand as determined by the LINGRA pasture production simulation model. Rainfall and temperature data were obtained from NIWA (http://cliflo. niwa.co.nz). Potential yield, "Actual" yield and Evapotranspiration (ET) deficit estimated by the simulation model as outlined in the text. Values (except Taranaki) are the mean of 10 years from 2002 to 2011 with maximum and minimum for the period in parentheses. (Taranaki data are for 2003 to 2011.)

\begin{tabular}{|c|c|c|c|c|c|c|}
\hline \multirow[b]{2}{*}{ Region } & \multicolumn{3}{|c|}{ NIWA input data } & \multicolumn{3}{|c|}{ LINGRA model outputs } \\
\hline & $\begin{array}{l}\text { Annual Rainfall } \\
(\mathrm{mm})\end{array}$ & $\begin{array}{c}\text { Nov-Mar rainfall } \\
(\mathrm{mm})\end{array}$ & $\begin{array}{l}\text { Feb. mean daily } \\
\text { max. temp }\left({ }^{\circ} \mathrm{C}\right)\end{array}$ & $\begin{array}{l}\text { Potential yield } \\
\text { (t DM/ha/yr) }\end{array}$ & $\begin{array}{l}\text { "Actual” yield } \\
\text { (t DM/ha/yr) }\end{array}$ & $\begin{array}{l}\text { Nov-Mar ET } \\
\text { deficit }(\mathrm{mm})\end{array}$ \\
\hline Waikato & $\begin{array}{c}1121 \\
(941-1387)\end{array}$ & $\begin{array}{c}395 \\
(179-641) \\
\end{array}$ & $\begin{array}{c}23.9 \\
(20.1-25.4)\end{array}$ & $\begin{array}{c}19.9 \\
(19.5-20.3)\end{array}$ & $\begin{array}{c}14.8 \\
(10.7-16.6)\end{array}$ & $\begin{array}{c}180 \\
(\mathrm{~S} 55-433)^{1}\end{array}$ \\
\hline Taranaki & $\begin{array}{c}1908 \\
(1480-2397)\end{array}$ & $\begin{array}{c}629 \\
(371-1024)\end{array}$ & $\begin{array}{c}21.3 \\
(18.8-22.6)\end{array}$ & $\begin{array}{c}18.9 \\
(18.3-19.5)\end{array}$ & $\begin{array}{c}15.7 \\
(12.8-17.0)\end{array}$ & $\begin{array}{c}38 \\
(\mathrm{~S} 442-452)^{1}\end{array}$ \\
\hline $\begin{array}{l}\text { Manawatu } \\
\text { Alluvial }\end{array}$ & $\begin{array}{c}970 \\
(646-1307)\end{array}$ & $\begin{array}{c}354 \\
(223-615)\end{array}$ & $\begin{array}{c}22.9 \\
(20.7-25.2)\end{array}$ & $\begin{array}{c}18.9 \\
(17.8-19.7)\end{array}$ & $\begin{array}{c}12.7 \\
(8.8-16.9)\end{array}$ & $\begin{array}{c}258 \\
(106-432)\end{array}$ \\
\hline Canterbury & $\begin{array}{c}603 \\
(383-843)\end{array}$ & $\begin{array}{c}214 \\
(124-320)\end{array}$ & $\begin{array}{c}21.4 \\
(19.3-23.7)\end{array}$ & $\begin{array}{c}17.6 \\
(17.1-18.0)\end{array}$ & $\begin{array}{c}6.8 \\
(3.6-10.4)\end{array}$ & $\begin{array}{c}447 \\
(324-614)\end{array}$ \\
\hline Southland & $\begin{array}{c}1134 \\
(975-1320)\end{array}$ & $\begin{array}{c}489 \\
(380-658)\end{array}$ & $\begin{array}{c}18.3 \\
(16.3-19.9)\end{array}$ & $\begin{array}{c}15.8 \\
(15.1-16.2)\end{array}$ & $\begin{array}{c}13.4 \\
(12.1-14.9)\end{array}$ & $\begin{array}{c}74 \\
(\mathrm{~S} 115-231)^{1}\end{array}$ \\
\hline
\end{tabular}

${ }^{1} \mathrm{~S}$ denotes water surplus in a season with above average summer rainfall. 


\section{Glasshouse experiments}

Data presented are from a series of six experiments conducted as part of a $\mathrm{PhD}$ study at Massey University by one of the authors (SH). Experiment 1 compared growth of potted 'Medea' and 'Grasslands Samson' plants in $30 \mathrm{~cm}$ deep pots in winter 2008. The remaining five experiments compared summer growth of 'Medea' and 'Grasslands Samson' plants, or of their F1 and/or F2 hybrids, grown in $90 \mathrm{~cm}$ deep pots. Experiments 2 also included plants of an unreleased tetraploid breeding line (referred to hereafter as a "cultivar" for brevity) derived from 'Grasslands Samson' and plants of cultivar 'Tolosa' reported by Stewart (2006) to incorporate Spanish germplasm. Experiment 5 included cultivar 'Ceres One50', also incorporating Spanish germplasm, and 'Matrix', bred through introgression of ryegrass with meadow fescue (Stewart 2006). Both Experiments 2 and 5 comprised a factorial combination of four cultivars $\times$ two water regimes (well watered or water rationed) $\times$ two harvest dates (early summer or mid-summer), with three replicates, making 48 pots in total. Experiment 2 was set up on 2 September 2008 with a final harvest in late December 2008. Experiment 5 ran from 20 September 2010 to 24 January 2011. Experiment 3 ran from March 2009 to February 2010, and compared five family groups comprising a 'Grasslands Samson' and 'Medea' parent plant and three $F_{1}$ progeny from each set of parents with two clonal replicates of each plant genotype. Measurements on the three experiments included root mass and gravimetric soil moisture in three soil depths; herbage mass, tiller number and percent tillers flowering above ground, and various leaf water relations measurements including leaf water potential (LWP) measured with a Scholander pressure chamber, leaf OP measured with a Wescor psychrometer fitted with HR33T chambers and used in the dew point mode, and temperature difference between the leaf canopy and the air (not reported) measured with an infrared thermometer, among others. Procedures for the various measurements closely followed those reported by Assuero et al. (2000). Data from Experiments 2 and 5 were statistically analysed using a factorial ANOVA model with the GLM procedure of SAS 9.2 (SAS Institute Inc., NC, USA). Specifically, sums of squares were fitted for the 4 cultivars, 2 water regimes, and 2 harvest dates and their interactions, and for replicates. This presentation focusses on the plant morphology of 'Medea' and its $F_{1}$ hybrids as compared to the commercial New Zealand cultivars named above.

\section{Results and Discussion \\ Regional variation in moisture deficit}

The modelling work focuses on the amount of water needed for ryegrass to maintain production in summer, and it should be noted that an alternative strategy - to breed for dormancy during drought and rapid recovery after drought - is not explored here. The model output is intended to stimulate discussion and promote clarity of thinking as the New Zealand pastoral industry plans future strategies, and not as a definitive comment. While a conceptually similar result could be achieved through compiling water balances from weather data, an advantage of the LINGRA model output is a comparative assessment of regional potential pasture production and limitation attributable to summer moisture deficit.

The assessed potential production (water nonlimiting) reduces from $19.9 \mathrm{t} \mathrm{ha}^{-1} \mathrm{yr}^{-1}$ in the Waikato to $15.8 \mathrm{t} \mathrm{ha}^{-1} \mathrm{yr}^{-1}$ in Southland (Table 1), with the difference attributable to decreased solar radiation and colder winter temperatures at higher latitude.

A range of other model outputs is available, but the modelled November-March ET deficit is presented as a useful measure of agronomic "persistence stress" faced by a pasture. The modelled November-March ET deficit ranks by region Taranaki $<$ Southland $<$ Waikato $<$ Manawatu $<$ Canterbury (Table 1). This will not be a surprise in industry circles, but a numerical measure of the gradation is helpful. Another measure of intensity

Table 2. Modelled outcomes obtained with the LINGRA model for three different breeding targets aimed at improving drought tolerance in perennial ryegrass: $10 \mathrm{~cm}$ increase in root depth, plant osmotic potential (OP) more negative by approx. 0.4 $\mathrm{MPa}$, and $10 \%$ change to model parameter controlling water use efficiency (WUE) modelled by suppressing decrease in photosynthesis at the onset of drought. The base scenario is as for a Manawatu alluvial soil in Table 1 with $354 \mathrm{~mm}$ mean summer rainfall and an ET deficit of $258 \mathrm{~mm}$.

\begin{tabular}{lcccc}
\hline & Base scenario & $\begin{array}{c}\text { Increased root } \\
\text { depth }(10 \mathrm{~cm})\end{array}$ & $\begin{array}{c}\text { More negative OP } \\
(0.4 \mathrm{MPa})\end{array}$ & $\begin{array}{c}\text { Increased WUE } \\
(10 \%)\end{array}$ \\
\hline Annual yield (t DM ha-1) & 12.71 & 13.39 & 12.70 & 13.09 \\
\hline Summer yield (t DM ha-1) & 4.97 & 5.48 & 4.56 & 5.20 \\
\% 'water non-limited' yield & 49.1 & 54.1 & 45.1 & 51.3 \\
Transpiration (mm) & 214 & 230 & 217 & 214 \\
WUE (kg DM ha-1 $\left.\mathrm{mm}^{-1}\right)^{\mathrm{a}}$ & 14.0 & 15.5 & 12.9 & 14.7 \\
\hline
\end{tabular}

aWUE for the November-March period. 
of plant stress is obtained by expressing the modelled November-March DM production ( $\mathrm{kg} \mathrm{DM} \mathrm{ha-1)}$ as a percentage of values obtained with water non-limiting. These values were, respectively: Taranaki, $72.0 \%$; Southland, 76.7\%; Waikato, 58.3\%; Manawatu, 49.1\%; and Canterbury, $18.1 \%$. It is also helpful to appreciate that a dry summer in Manawatu or Waikato generates similar agronomic stress on pasture (as measured by ET deficit of approx. $450 \mathrm{~mm}$ ) to that of an average summer in Canterbury, where ryegrass is considered to need irrigation for dairy farming.

\section{Modelled outcome of breeding strategies for moisture deficit tolerance}

Under the model assumptions, for Manawatu, a rooting depth increase of $10 \mathrm{~cm}$ increased summer transpiration by $16 \mathrm{~mm}$, WUE by $1.5 \mathrm{~kg} \mathrm{DM} \mathrm{ha}^{-1} \mathrm{~mm}^{-1}$, and summer pasture production by $0.51 \mathrm{t} \mathrm{DM} \mathrm{ha}^{-1}$. More negative OP of approximately $0.4 \mathrm{MPa}$ was (unexpectedly) predicted to slightly decrease herbage production, and increased WUE was predicted to increase summer yield by $0.23 \mathrm{t} \mathrm{DM} \mathrm{ha}^{-1}$ (Table 2 ).
A deeper rooting depth resulted in drainage loss reducing from 45 to $27 \mathrm{~mm} \mathrm{yr}^{-1}$, largely explaining the transpiration increase (Table 2). In another recent study, White \& Snow (2012) predicted a $10-\mathrm{cm}$ increase in rooting depth to increase WUE by $0.5 \mathrm{~kg} \mathrm{DM} \mathrm{ha}^{-1} \mathrm{~mm}^{-1}$. Nevertheless, the modelled increase in transpiration of $16 \mathrm{~mm}$ with $10 \mathrm{~cm}$ increase in root depth is relatively small compared to the Manawatu ET deficit, and there may be side effects if root system size is increased at the expense of leaf production.

A more negative root water potential enables the plant to capture the soil water faster, but it does not increase the amount of available water. Such a grass might run out of water faster in dry summer conditions than under the base scenario, which could lead to longer periods of severe water deficiency and subsequent yield loss. It has been suggested that drought tolerance may be improved by buffering the rate of soil water use by the crop, especially at the start of the growing season, so that drought tolerance might, paradoxically, be attained by breeding plants with a lower root/shoot ratio (Passioura 1983).

Table 3. Cultivar and moisture regime "main effects" for selected measurements to assess moisture-deficit response of ryegrass. Experiment 2: tiller number per plant, shoot DW (SDW), \% flowering tillers, root mass $\left(\mathrm{g} \mathrm{pot}^{-1}\right)$, gravimetric soil moisture (GSMC) for three soil depths ${ }^{1}$, root:shoot ratio (R:S) and an index of deep rootedness (Index DR, ratio of sum of d2 and d3 root mass to total root mass). Experiment 5: tiller number per plant, shoot DW, \% flowering tillers, GSMC d2, R:S, Index DR, leaf water potential (LWP, MPa), and leaf osmotic potential (OP, MPa).

\begin{tabular}{|c|c|c|c|c|c|c|c|c|}
\hline \multirow[t]{2}{*}{ Experiment 2} & \multicolumn{4}{|c|}{ Cultivar } & & \multicolumn{3}{|c|}{ Water Regime } \\
\hline & Medea & G. Samson & Samson (4n) & Tolosa & SEM & Cont. & Stress & SEM \\
\hline Tiller No. & 31.3 & 51.9 & 36.1 & 55.1 & 3.13 & 49.6 & 38.0 & 2.21 \\
\hline SDW $\left(\mathrm{g} \mathrm{pot}^{-1}\right)$ & 18.34 & 29.68 & 30.90 & 31.09 & 1.35 & 32.5 & 22.5 & 0.95 \\
\hline Flowering \% & 34.4 & 1.7 & 15.0 & 0.0 & 2.19 & 17.0 & 8.5 & 1.55 \\
\hline Root d1 $\left(\mathrm{g} \mathrm{pot}^{-1}\right)$ & 4.43 & 7.05 & 6.66 & 5.29 & 0.458 & 7.25 & 4.46 & 0.324 \\
\hline Root d2 $\left(\mathrm{g} \mathrm{pot}^{-1}\right)$ & 1.84 & 1.61 & 1.45 & 1.18 & 0.135 & 1.60 & 1.44 & 0.096 \\
\hline Root d3 (g pot ${ }^{-1}$ ) & 0.92 & 0.45 & 0.53 & 0.55 & 0.072 & 0.64 & 0.58 & 0.051 \\
\hline GSMC d1 (\%) & 9.44 & 7.71 & 7.67 & 7.96 & 0.407 & 9.9 & 6.4 & 0.288 \\
\hline GSMC d2 (\%) & 7.00 & 5.28 & 5.35 & 6.33 & 0.263 & 6.8 & 5.2 & 0.186 \\
\hline GSMC d3 (\%) & 7.63 & 6.74 & 7.16 & 8.18 & 0.402 & 7.8 & 7.0 & 0.284 \\
\hline $\mathrm{R}: \mathrm{S}$ & 0.43 & 0.31 & 0.29 & 0.23 & 0.017 & 0.30 & 0.32 & 0.012 \\
\hline Index DR & 0.39 & 0.23 & 0.24 & 0.25 & 0.018 & 0.25 & 0.31 & 0.013 \\
\hline \multirow[t]{2}{*}{ Experiment 5} & \multicolumn{5}{|c|}{ Cultivar } & \multicolumn{3}{|c|}{ Water Regime } \\
\hline & Medea & G. Samson & Ceres One50 & Matrix & SEM & Cont. & Stress & SEM \\
\hline Tiller No. & 38.1 & 102.3 & 183.8 & 215.5 & 15.32 & 140.8 & 129.1 & 10.89 \\
\hline SDW $\left(\mathrm{g} \mathrm{pot}^{-1}\right)$ & 3.80 & 11.58 & 21.93 & 25.35 & 1.61 & 16.82 & 14.51 & 1.14 \\
\hline Flowering \% & 36.9 & 19.7 & 1.03 & 0.3 & 2.67 & 17.5 & 11.2 & 1.89 \\
\hline $\mathrm{R}: \mathrm{S}$ & 0.56 & 0.22 & 0.21 & 0.23 & 0.072 & 0.26 & 0.35 & 0.051 \\
\hline Index DR & 0.28 & 0.24 & 0.16 & 0.15 & 0.026 & 0.15 & 0.26 & 0.018 \\
\hline GSMC d2 & 15.48 & 15.05 & 13.76 & 13.08 & 0.75 & 17.31 & 11.38 & 0.53 \\
\hline LWP (MPa) & -1.13 & -0.82 & -1.09 & -0.90 & 0.069 & -0.80 & -1.16 & 0.048 \\
\hline OP (MPa) & -3.08 & -2.05 & -2.16 & -2.16 & 0.268 & -2.26 & -2.46 & 0.197 \\
\hline
\end{tabular}

${ }^{1}$ Experiment 2: $\mathrm{d} 1,0-30 \mathrm{~cm}$; d2, $30-55 \mathrm{~cm}$; d3 below $55 \mathrm{~cm}$ soil depth; Experiment 5: $\mathrm{d} 1,0-40 \mathrm{~cm}$; $\mathrm{d} 2,40-70 \mathrm{~cm}$; $\mathrm{d} 3 \mathrm{below}$ $70 \mathrm{~cm}$ soil depth. 
Breeding for an increased WUE under dry conditions basically provides more biomass with the same amount of water. The choice of modelling a $10 \%$ increase in WUE was arbitrary and may underestimate the progress available through plant breeding.

More generally, the issues faced by plants to maintain water supply in summer are not always well appreciated. The water use efficiencies of $13-15 \mathrm{~kg}$ DM $\mathrm{ha}^{-1} \mathrm{~mm}^{-1}$ in Table 2 convert to $650-750$ litres water $\mathrm{kg}$ $\mathrm{DM}^{-1}$, and as the soil dries in summer plant tissues need to build osmotic potential to continue to extract water, typically attaining values exceeding $2 \mathrm{MPa}$ (Table 3 ). To put this in perspective, plant cells at $2 \mathrm{MPa}$ osmotic potential require about $10 \times$ the pressure in a car tyre to force water out of them.

This analysis shows that it is unrealistic for the industry to hope for breeders to produce a ryegrass cultivar that can maintain high production in drier regions or summers in New Zealand as there is simply not enough water available. At best, the thresholds for ryegrass might be moved so that it could extract an extra $30-50 \mathrm{~mm}$ of water in a drier summer. This would provide welcome amelioration of water deficit stress in a season with below average rainfall or in drier regions, but not more than that. Perhaps this indicates the need for a systematic review of water resources and the question of the planned use of available water for irrigation purposes.

\section{Cultivar differences in drought tolerance traits}

Compared to the New Zealand cultivars, 'Medea' had a smaller shoot mass in summer and a greater proportion of root mass at depth, these traits combining to offer a measure of soil moisture conservation (Table 3). However, the loss of DM yield associated with this drought tolerance strategy would likely be unwelcome in many New Zealand farming systems. Another trait of 'Medea' which would be regarded as a negative in New Zealand is the tendency for a high percentage of tillers to flower (Table 3). Similar behaviour was also seen in 'El Palenque' tall fescue of North African origin (Assuero et al. 2000). However, in contrast to this North African-derived tall fescue, which had reduced osmotic adjustment compared to European cultivars, LWP and OP of 'Medea' ryegrass in Experiment 5 was more negative than for the New Zealand cultivars $(\mathrm{P}=$ 0.036). (LWP and OP were not measured in Experiment 2.)

A notable observation was that whereas young plants of 'Medea' possessed more root mass at depth than plants of 'Grasslands Samson' in Experiment 2 and a higher proportion of the total root mass at depth (Index DR) in Experiments $2 \& 5$ (Table 3), for older plants in Experiment 3, 'Grasslands Samson' had a higher

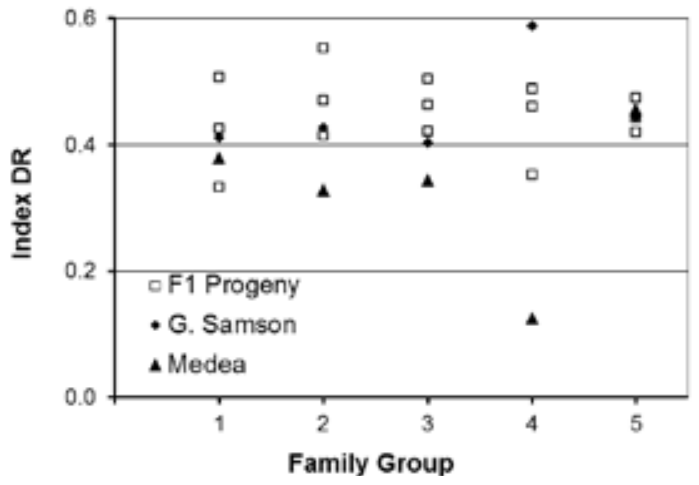

Fig. 1. Distribution of values for index of deep rootedness (Index DR) among five family groups comprising a 'Medea' and a 'Grasslands Samson' parent and $3 \mathrm{~F}_{1}$ progeny in Experiment 3. Data are means of 2 clonal replicates in each case. Parental means were: 'Medea' $0.33 \pm 0.032$, 'Grasslands Samson' 0.45 (SE 0.032, $\mathrm{P}=0.012$ ). Progeny mean was 0.45 (SE 0.019). The interaction between family group and means for parents and progeny was not statistically significant $(P>0.05)$, but became so when weight of deep roots was expressed as a fraction of shoot weight.

Index DR than 'Medea' (Fig. 1). This indicates that any future selection for root-related traits will need to take account of effects of plant age on root system structure. While the number of genotypes included in Experiment 3 was small compared to numbers of plants used in a typical breeding programme, initial indications are (Fig. 1) that 'Medea' $F_{1}$ progeny can exhibit transgressive segregation for deep rootedness in some families. This was confirmed in a subsequent experiment (data not reported), but the deep rootedness trait was largely absent from the F2 generation in that experiment. Hence 'Medea' potentially could provide a source of genes for deep rootedness in a breeding programme, but to find elite individuals, assessment of large numbers of plants for this trait might be required.

'Tolosa' was included in Experiment 2 and 'Ceres One50' in Experiment 5 specifically because of their breeding background incorporating Spanish germplasm (Stewart 2006), in order to explore the drought tolerance traits exhibited. In Experiment 2, 'Tolosa' produced similar shoot dry weight to 'Grasslands Samson' but apparently, based on respective gravimetric soil moisture values of 6.33 and 5.28 (Table 3; $\mathrm{P}<0.05$ ), used soil moisture more slowly, implying improved WUE. In Experiment 5, 'Ceres One50' and 'Matrix' both produced much higher shoot dry weight than 'Grasslands Samson', though with slightly greater soil moisture reduction in doing so (Table 3). This is consistent with, but not proof of, increased WUE in these cultivars, but as daily maximum glasshouse temperatures frequently exceeded $30^{\circ} \mathrm{C}$ in both 
experiments the role of high temperature tolerance in these results needs to be clarified in future work.

\section{Conclusions}

Five key conclusions that can be drawn from this work are:

- It is unrealistic to expect plant breeders to produce a perennial ryegrass that can maintain high summer production in the drier regions of New Zealand, or in dry summers in some of our traditional pastoral farming regions; there is simply not enough water available;

- A greater focus on planning of use of water resources for irrigation might be considered;

- Modelling indicates that plant breeding targeting greater rooting depth or improved WUE could feasibly provide the equivalent of another $30-50$ $\mathrm{mm}$ rainfall in a dry summer;

- The Mediterranean germplasm explored in this study could possibly act as a source of genes for a deeper rooting ryegrass;

- Introgression of Spanish germplasm for improved summer moisture deficit tolerance appears to have produced useful benefits.

\section{ACKNOWLEDGEMENTS}

We thank Higher Education Commission Pakistan for provision of a PhD scholarship for S. Hussain, and the T.R. Ellett Agricultural Trust for supplementary $\mathrm{PhD}$ stipend funding. We thank staff of the Massey University Institute of Natural Resources, S. Ray, L. Taylor, L. Sylva, S. Avery, C. Rawlingson, M. Osborne, S. Orsborn, J. Slater, K. Sinclair, and B. Pietresson de St. Aubin of La Salle Beauvais, France, for technical assistance with water relations and root measurements. We also thank J. Wolf and P. Leffelaar of the Plant Production Systems Group, Wageningen University, for making the LINGRA model available to us, and for their help.

\section{REFERENCES}

Assuero, S.G.; Matthew, C.; Kemp, P.D.; Hodgson, J.; Latch, G.C.M.; Barker, D.J.; Haslett, S.J. 2000. Morphological and physiological effects of water deficit on contrasting tall fescue cultivars with and without endophyte. New Zealand Journal of Agricultural Research 43: 49 - 61.
DairyNZ. 2012. DairyNZ forage value index. Downloaded 8 June 2012 from: http://www. dairynzfvi.co.nz/select/cultivar-selector/view-uppernorth-island?Region $=1$

Glassey, C.B. 2011. Summer pasture yield variation in a central Waikato location from 1979 to 2010: Implications for pasture persistence. Pasture persistence symposium. Grassland Research and Practice Series No. 15: 15-20

Hunt, W.F.; Easton H.S. 1989. Fifty years of ryegrass research in New Zealand. Proceedings of the New Zealand Grassland Association 50:11-23.

Kraalingen, D.W.G. van. 1995. The FSE System for Crop Simulation, Version 2.1. Quantitative Approaches in System Analysis No. 1. C.T. de Wit Graduate School for Production Ecology, Wageningen, 27 pp.

Lee, J.M.; Matthew, C.; Thom, E.R.; Chapman, D.F. 2012. Perennial ryegrass breeding in New Zealand: a dairy industry perspective. Crop and Pasture Science 63: 107-127.

NIWA. 2012. CLIFLO, The National Climate Database, http://cliflo.niwa.co.nz/

Passioura, J.B. 1983. Roots and drought resistance. Agricultural Water Management 7: 265-280.

Reed, K.F.M. 1996. Improving the adaptation of perennial ryegrass, tall fescue, phalaris, and cocksfoot for Australia. New Zealand Journal of Agricultural Research 39: 457-464.

Schapendonk, A.H.C.M.; Stol, W.; Kraalingen D.W.G. van; Bouman, B.A.M. 1998. LINGRA, a sink/source model to simulate grassland productivity in Europe. European Journal of Agronomy 9: 87-100.

Silsbury, J.H. 1961. A study of dormancy, survival and other characteristics in Lolium perenne L. at Adelaide, SA. Australian Journal of Agricultural Research 12: 1-9.

Stewart,A.V. 2006. Genetic origins of perennial ryegrass (Lolium perenne) for New Zealand pastures. pp 11$20 \mathrm{In}$ : Breeding for Success: Diversity in Action. Proceedings of the 13th Australasian Plant Breeding Conference, Christchurch, New Zealand 18-21 April 2006. New Zealand Grassland Association, Dunedin. White, T.A.; Snow, V.O. 2012. A modelling analysis to identify plant traits for enhanced water-use efficiency of pasture. Crop and Pasture Science 63: 63-76. 